Терапевтична стоматологія

УДК 616.37-036, 12+616.314.17]-097

DOI

(C) А. В. Чорній, В. В. Шманько

ДВНЗ «Тернопільський державний медичний університет

імені І. Я. Горбачевського»

\title{
Вплив захворювань щитоподібної залози на стоматологічний статус людини (огляд літератури)
}

Резюме. У статті розглянуто проблему впливу захворювань щитоподібної залози на стоматологічне здоров’я людини. Звернено увагу на розповсюдження та характер перебігу патологічних процесів у пародонті, поширеність карієсу та некаріозних уражень у хворих із порушенням функції щитоподібної залози.

Ключові слова: захворювання щитоподібної залози, пародонтит, карієс.

\section{А. В. Чорний, В. В. Шманько}

ГВУЗ «Тернопольский государственный медицинский университет

имени И. Я. Горбачевского»

\section{Влияние заболеваний щитовидной железы на стоматологический статус человека (обзор литературы)}

Резюме. В статье рассмотрено проблему влияния заболеваний щитовидной железы на стоматологическое здоровье человека. Обращено внимание на распространённость и характер протекания патологических процессов в пародонте, распространённость кариеса и некариозных поражений у больных с нарушением функции щитовидной железы.

Ключевые слова: заболевания щитовидной железы, пародонтит, кариес.

\section{A. V. Chorniy, V. V. Shmanko}

I. Horbachevsky Ternopil State Medical University

\section{The influence of thyroid disease in human dental status (literature review)}

Summary. The article adduces the problem of influence of thyroid disease on dental human health. Attention is paid to spread and character of pathological processes in periodontal prevalence of caries and non-carious lesions in patients with thyroid dysfunction.

Key words: thyroid disease, periodontal disease, tooth decay.

Йододефіцитні захворювання становлять важливу медико-соціальну проблему, оскільки значна територія України, за біогеохімічними показниками, характеризується низьким вмістом йоду в навколишньому середовищі. За даними різних авторів, показники поширеності субклінічного гіпотиреозу перебувають у межах від 1,2 до 15 \% залежно від статі й віку обстежених, у середньому в 6 \% загальної популяції, що значно перевищує частоту клінічно явного гіпотиреозу (0,3-1,1 \%). 
Субклінічний гіпотиреоз майже втричі частіше спостерігають у жінок, ніж у чоловіків. Якщо серед чоловіків частота субклінічного гіпотиреозу становить 2,8-3 \%, то серед жінок - 7,5 \% [22, 25]. За останні десятиліття як у всьому світі, так і в нашій країні дифузний токсичний зоб має не тільки велике поширення, але й тенденцію до постійного зростання. Частота захворюваності, за різними даними, становить 0,5 на 1000 жінок і 0,1 на 1000 чоловіків із максимальним піком у віці 4060 років [13]. Тому велику увагу приділяють вивченню різних патологій організму на тлі захворювань щитоподібної залози.

Це стало підставою для аналізу літературних джерел щодо впливу захворювань щитоподібної залози на стоматологічний статус людини. Пошук літератури відбувався у бібліотечних джерелах та пошукових системах http://www.google.com.ua, http:// www.yandex.ru, www.meta.ua, www. rambler.ru, Pub Med.

Результати аналізу літературних даних показав, що йод надходить у клітини щитоподібної залози і бере активну участь у синтезі тиреоїдних гормонів - тироксину і трийодтироніну [18]. Гормони щитоподібної залози беруть активну участь у розвитку та регуляції функції нервової системи та психіки, серцево-судинної системи, органів травлення, репродуктивної функції та кістково-м'язової системи [4]. Синдром гіпотиреозу найчастіше супроводжує такі захворювання щитоподібної залози, як ендемічний зоб, аутоімунний тиреоїдит, післяопераційний гіпотиреоз [10]. Дифузний токсичний зоб - захворювання, що супроводжується дифузними гіперпластичними змінами у щитоподібній залозі та інтоксикацією організму тиреоїдними гормонами. Вони впливають на активність і обмін численних ферментів, вітамінів, мінералів, гормонів та метаболічну функцію всіх органів, систем і тканин людини $[3,12]$.

Урядіфундаментальних наукових досліджень виявляється тісний взаємозв'язок стоматологічних захворювань із патологією ендокринної системи. У структурі ендокринної патології значна частка припадає на захворювання щитоподібної залози. Відомо, що обмінні порушення i порушення у різних органах та системах організму перебувають під впливом функції щитоподібної залози $[1,8]$.

Захворювання пародонта у хворих на токсичний зоб бувають у віці від 20 до 40 років, частота його може сягати до $83 \%$. Частота пародонтиту в пацієнтів із токсичним зобом перебуває у прямій залежності від тривалості захворювання і залежить від його тяжкості [5, 24]. На виникнення і розвиток захворювань пародонта у даної групи осіб впливають численні фактори, які сприяють зниженню реактивності організму і призводять до розвитку вторинної імунної недостатності та зниження резистентності тканин пародонта до бактеріальної інвазії. Істотний вплив на імунну відповідь надає ендокринна система, яка входить у комплекс нейроендокринної регуляції організму [6, 9, 30].

В експериментальних умовах встановлено, що гіпотиреоз і гіпертиреоз спричиняють дистрофічні та запальні зміни в тканинах пародонта з утворенням пародонтальних кишень, резорбцією кістки коміркового відростка, рухомістю та втратою зубів $[17,20]$. Видалення щитоподібної залози також спричинює дистрофічнозапальні процеси в пародонті [22, 32, 43]. У хворих із порушеннями функції щитоподібної залози існує взаємозв'язок між поширеністю захворювань пародонта (генералізованого пародонтиту) 3 давністю захворювання та активністю процесу [21, 28, 42]. 3 іншого боку, під час вивчення функціонального стану щитоподібної залози у хворих на генералізований пародонтит спостерігають певні порушення їі функції, тобто тенденцію до зниження ії активності [3, 26, 37]. Пародонтит у хворих на тиреотоксикоз є проявом загального порушення обміну речовин, викликаного захворюванням щитоподібної залози. Деякі автори вказували на прогресуючу форму пародонтиту при токсичному зобі. Багато дослідників не знаходить прямої залежності між ураженням пародонта і тяжкістю захворювання щитоподібної залози. Проте відомо, що захворювання шлунково-кишкового тракту впливають на стан пародонта, але експериментально 
встановлено вплив гормонів щитоподібної залози на секрецію шлунка [10, 27, 39].

Серед етіологічних чинників розвитку карієсу виділяють порушення мінерального, вуглеводного, білкового, вітамінного та інших видів обміну речовин.

Відомо, що при захворюваннях щитоподібної залози порушуються усі види обміну речовин. Це приводить до утворення ерозій емалі та дентину, некрозу емалі в ділянці шийок зубів і при цьому спостерігають гіперестезію дентину, а також патологічне стирання зубів, що є наслідком порушення метаболізму в тканинах зуба. Порушення білкового та фосфорнокальцієвого обмінів може впливати на процеси ремінералізації емалі та дентину, а також на утворення замісного дентину. Ряд вчених вказує, що у хворих на токсичний зоб спостерігають множинний карієс і патологічне стирання зубів [19, 44]. Виявлено високу інтенсивність карієсу (КПУ) в пацієнтів із токсичним зобом, що в середньому дорівнювала 11,2 [34, 45].

Ю. М. Макашовський та співавт. (1980) у 70 \% хворих із тривалістю захворювання більше 4 років виявили, крім карієсу, ерозіі твердих тканин зубів. М. А. Єфремов (1973) зазначає, що у хворих на тиреоток-

\section{Список літератури}

1. Абдул Гафар. Запалення, захворювання пародонту та здоров’я організму / Гафар Абдул, Р. Энтони // Современная стоматол. - 2005. - № 3. С. 61-64.

2. Клинико-морфологические взаимосвязи потери минеральной плотности кости при заболеваниях пародонта на фоне соматической патологии / С. Д. Арутюнов, А. Л. Верткин, О. В. Зайратянц [и др.]. // Институт стоматологии. - 2008. - № 2. С. 88-91.

3. Бабушкина Н. С. Экспериментальное исследование воздействия токсических доз кальция и брома, а также профилактической эффективности «Биоля» и «Витафтора» / Н. С. Бабушкина // Таврический медико-биологический вестник. 2009. - № 1. - С. 115-117.

4. Боднар П. М. Йододефіцитні розлади - актуальна медико-соціальна проблема // Лікарська справа. - 2001. - № 3. - С. 7-9.

5. Годованець О. I. Стан сполучнотканиних елементів зубощелепної системи у дітей при дифузному нетоксичному зобі / О. I. Годованець, М. М. Рожко, Г. М. Ерстенюк // Актуальні проблеми сучасної медицини : вісник Української медичної стоматологічної академії. - 2014. - № 3. - С. 39-42. сикоз дентиклі у пульповій камері зубів зустрічаються майже в 3 рази частіше. Доведено, що гормон тирокальцитонін володіє гіпокальціємічною дією і гальмує резорбцію кістки особливо у випадках іï посиленого катаболізму, при патологічних процесах і посттравматичній регенерації [33, 36, 45].

При обстеженні порожнини рота у хворих на тиреотоксикоз відмічають значну набряклість усієї слизової оболонки, у $93 \%$ хворих - ціаноз, у 30 \% - атрофію, а у 8 \% гіпертрофію сосочків язика, у 46 \% хворих спостерігали хронічний катаральний гінгівіт [29, 34, 40 ].

Отже, особливості перебігу захворювань тканин пародонта, слизової оболонки ротової порожнини та твердих тканин зуба в осіб із порушеною функцією щитоподібної залози, як і їх лікування, $\epsilon$ недостатньо вивчені. Тому такі коморбідні стани потребують подальшого дослідження і розробки нових схем комбінованої фармакотерапії та диференційного підходу до лікування залежно від характеру порушення (еутиреоз, гіпотиреоз, гіпертиреоз). Це дасть можливість суттєво підвищити ефективність лікування таких захворювань.

6. Годованець О. I. Особливості становлення зубощелепової системи у дітей із дифузним нетоксичним зобом / О. І. Годованець, М. М. Рожко // Вісникпроблембіологіїімедицини.-2015.-Вип. 2, т. 2(119). - С. 37-39.

7. Грудянов А. И. Заболевания пародонта / А. И. Грудянов М. : Медицинское информационное агентство, 2009. - 336 с.

8. Горбачёва И. А. Единство системных патогенетических механизмов при заболеваниях внутренних органов, ассоциированных с генерализованным пародонтитом / И. А. Горбачёва, А. И. Кирсанов, Л. Ю. Орехова // Стоматология. - 2004.- № 3.- С. 6-11.

9. Гударьян А. А. Компоненты метаболического синдрома у больных воспалительными заболеваниями пародонта / А. А. Гударьян // Вісн. стоматол. Спеціальний випуск. - 2005. - № 1. - С. 28-34. 10. Дидив И. И. Эндокринология / И. И. Дидив, Г. А. Мельниченко, В. В. Фадеевю - ГЭОТАР-Медиа, 2007. - 432 с.

11. Заверная А. М. Методы оценки и коррекции имунных нарушений у больных дистрофическивоспалительными и воспалительно-дистрофическими заболеваниями пародонта и слизистой 
оболочки полости рта / А. М. Заверная, Т. Н. Волосовец, А. С. Андрусенко // Дентальные технологии. - 2005. - № 5/6. - С. 13-15.

12. Зелінська Н. Б. Стан надання спеціалізованої допомоги дітям 3 ендокринною патологією в Україні у 2012 році та перспективи її розвитку / Н. Б. Зелінська, А. В. Терещенко, Н. Г. Руденко // Український журнал дитячої ендокринології. 2013. - № 3. - С. 31-39.

13. Зелінська Н. Б. Гіпотиреоз Центральна гемодинаміка і компенсація хвороби / Н. Б. Зелінська // Вісник ВНМУ. - 2003. - № 1,2. - С. 256.

14. Ішутко І. Ф. Вплив хімічних елементів на структуру і властивості емалі (огляд літератури) / I. Ф. Ішутко // Стоматолог. - 2014. - № 2. - С. 31-37. 15. Клинико-микробиологические аспекты и контроль эффективности консервативного лечения воспаления пародонта у больных сахарным диабетом 1 типа / В. Н. Царев, Г. М. Бабер, О. О. Якушевич [и др.] // Стоматология. - 2006. - № 4. - С. 40-46. 16. Колесова Н. А. Концепция гетерогенности болезней пародонта, определяющая особенности лечебной практики / Н. А. Колесова, А. М. Политун, Н. В. Колесова // Современная стоматология. 2006. - № 1. - С. 61-64.

17. Колесник К. А. Особенности костного метаболизма у детей с зубочелюстными аномалиями и сопутствующим дифузным нетоксическим зобом / К. А. Колесник, Н. Н. Каладзе, О. В. Деньга // Вісник стоматології. - 2013. - № 2. - С. 74-80.

18. Кондратьева Л. В. Лечение тиреотоксикоза / Л. В. Кондратьева, А. Ю. Попова // Терапевтический архив. - 2006. - Т. 78, № 2. - С. 42-44.

19. Кристаллографическое исследование смешанной нестимулированой слюны у пациентов с диффузным токсическим зобом / С. Н. Денисенко, А. А. Шапашникова, С. С. Григорьев [и др.] // Пробл. стоматол. - 2005. - № 2. - С. 739.

20. Кузняк Н. Б. Стоматологічна захворюваність у дітей з ендокринною патологією / Н. Б. Кузняк, О. І. Годованець, В. А. Гончаренко // Буковинський медичний вісник. - 2013. - Т. 12, № 2(44). С. 100-102.

21. Любарець С. Ф. Характеристика стану твердих тканин зубів та пародонта у дітей з хронічним тиреоїдитом та його фармакологічна корекція : автореф. дис. на здобуття наук. ступеня канд. мед. наук : спец. 14.01.22. "Стоматологія» / С. Ф. Любарець. - Київ, 2004. - 20 с.

22. Маменко М. Є. Йодний дефіцит та йододефіцитні захворювання (лекція) / М. Є. Маменко // Перинаталогия и педиатрия. - 2013. - № 1 (53). C. 97-105.

23. Мельник Н. С. Особливості перебігу генералізованого пародонтиту при дисфункції щитоподібної залози: вплив на структурнофункціональний стан кісткової тканини адльвеолярного відростка : автореф. дис. на здобуття наук. ступеня канд. мед. наук : спец. 14.01.22 «Стоматологія» / Н. С. Мельник - К., 2010. - С. 1-12. 24. Мельник Н. С. Особливості протікання генералізованого пародонтиту на фоні захворювань щитовидної залози / Н. С. Мельник // Дентальные технологии. - 2007. - № 1 (32). - С. 23-24.

25. Миронюк Н. І. Проблема йодного дефіциту та його подолання у населення Західного регіону України : автореф. дис. на здобуття наук. ступеня канд. мед. наук : спец. 14.01.14. «Педіатрія» / Н. І. Миронюк. - Київ, 2008. - 23 с.

26. Микроциркуляция тканей пародонта у больных сахарным диабетом и диффузным токсическим зобом по данным лазерной допплеровской флоуметрии / Р. Н. Нигматов, У. А. Ганиев, Д. К. Нужмутдинова [и др.] // Stomatologiya (Среднеазиатский научно-практический журнал). - 2003. - № 1/2. - С. 28-31.

27. Огонян А. В. Клинико-морфологические изменения зубо-челюстной системы при гипотиреозе : автореф. дисс. на соискание науч. степени кан. мед. наук : спец. 14.01.14. «Стоматология». 14.03.02. «Патологическая анатомия» / А. В. Огонян. - Ставрополь, 2010. - 22 с.

28. Паньків В. І. Субклінічний гіпотиреоз: стан проблеми та лікування / В. І. Паньків // Здоровье Украины. - 2006. - № 158. - С. 47-48.

29. Хронический генерализованный пародонтит у больных эндемическим зобом / Р. Т. Сутаева, С. Р. Минкаилова, И. М. Шамов, О. Г. Омаров // Вестник новых медицинских технологий. - 2012. T. XIX, № 3 - C. 46.

30. Цепов Л. М. Нерешенные вопросы этиологии и патогенеза воспалительных заболеваний пародонта / Л. М. Цепов, А. И. Николаев // Пародонтология. - 2001. - № 1 /2. - С. 28-31.

31. Цепов Л. М. Межсистемные связи при болезнях пародонта / Л. М. Цепов, А. И. Николаев // Пародонтология. - 2003. - № 2. - С. 19-24.

32. Черенько С. М. Сучасний стан проблеми діагностики та лікування хвороби Гревса й аутоімунної офтальмопатії / М. С. Черенько // Здоров’я України. - 2010. - № 1. - С. 58-59.

33. Шнейдер О. Л. Заболевания пародонта при гипофункции щитовидной железы (Обзор) / О. Л.Шнейдер, В.П. Журавлев//Урал. стоматол.ж.2004. - № 6. - С. 32-32.

34. Шустова А. О. Особенности диагностики, клиники и лечения стоматологических заболеваний у детей, проживающих в условиях йодного дефицита : дисс. канд. мед. наук / А. О. Шустова. Пермь, 2004.

35.Ярова С.П.Структура стоматологічноїпатології при серцево-судинних захворюваннях / С. П. Ярова, Н. В. Мозгова // Современная стоматология. 2006. - № 2. - C. 21-22.

36. Беляков Ю. А. Зубочелюстная система при эндокринных заболеваниях http://www.meddr.ru/ zubochelustnaya_sistema_pri_endokrinnyh_zabo/ zabolevaniya_schitovidnoy_zhelezy_i_dannye_s/ stomatologicheskie_proyavleniya_diffuznotok/14472.html

37. Arirachakaran P. Manganese affects Streptococcus mutans virulence gene expression / P. Arirachakaran, E. Benjavongkulchai, S. Luengpailin [et al.] // Caries Res. - 2007. - Vol. 41. - P. 503-511. 
38. Buzalaf M. A. R. Effect of an iron mouthrinse on enamel and dentine erosion subjected or not to abrasion: an in situ/ex vivo study / M. A. R. Buzalaf, S. H. C. Sales-Sales, J. P. Pessan // Arch. Oral. Biol. 2007. - Vol. 52. - P. 128-132.

39. Buzalaf M. A. R. Iron supplementation reduces the erosive potential of a cola drink on enamel and dentin in situ / stomatol M. A. R. Buzalaf, M. T. Kato // J. Appl. Oral Sci. - 2010. - Vol. 20. - P. 318 - 322.

40. Lynch R. J. M. Zinc in the mouth, its interactions with dental enamel and possible effects on caries; a review of the literature / R. J. M. Lynch // Int. Dent. J. 2011. - Vol. 61. - P. 46-54.

41. Shashikiran N. D. Estimation of trace elements in sound and carious enamel of primary and permanent teeth by atomic absorption spectrophotometry: an in vitro study / N. D. Shashikiran, V. V. Subba Reddy,
M. C. Hiremath // Indian J. Dent. Res. - 2007. Vol. 18. - P. 157-162.

42. Vanderpump M. P. Iodine status of UK schoolgirls: a cross-sectional survey / M. P. Vanderpump, J. H. Lazarus, P. P. Smyth [et al.] // Lancet. - 2011. Vol. 377. - P. 2007.

43. WHO, UNICEF, and ICCIDD. Assessment of the Iodine Deficiency Disorders and monitoring their elimination. Third edition. -Geneva : WHO, 2007. $98 \mathrm{p}$.

44. Zsiska M. Dentinal tubule occlusion with stannous fluoride and KNO3 /Gantrez dentifrices / M. Zsiska, M. Gibbs, J. A. Moore, J. C. Buisson, D. J. White // J. Dent. Res. - 2012. - Vol. 91. - P. 744.

45. Zimmermann M. B. Prevalence of iodine deficiency in Europe in 2010 / M. B. Zimmermann, M. Andersson // Ann. Endocrinol (Paris). - 2011. Vol. 72. - P. 164.

Отримано 03.02.16 